\title{
Mating Type Change in Pythium splendens Induced by Selfing
}

\author{
Li-Yun GUO,** and Wen-Hsiung $\mathrm{KO}^{*}$
}

\begin{abstract}
When $(+)$ and ( $(-)$ isolates of Pythium splendens were paired on the opposite sides of a polycarbonate membrane, oospores were produced by $(+)$ but not $(-)$ isolate. In addition to the original mating type, the opposite mating type appeared in the progeny derived from selfed oospores of most $(+)$ isolates tested. Occasionally self-fertile $( \pm)$ and neuter $(0)$ types were also detected. The self fertility nature of $( \pm)$ was unstable and transitory, segregating into $(+)$ and $(-)$ types during asexual reproduction. It was postulated that selfing may have changed the mating type by altering the function of a repressor which regulated the expression of mating types with different molecular configuration.
\end{abstract}

(Received January 16, 1995; Accepted June 14, 1995)

Key words : Pythium splendens, mating type change, selfing, oospores, hormone.

\section{INTRODUCTION}

When $(+)$ and $(-)$ isolates of Pythium splendens Braun were paired on opposite sides of a polycarbonate membrane, numerous oospores were produced by $(+)$ but not by the $(-)$ isolates ${ }^{7)}$. This suggests that sexual reproduction in this important soil-borne plant pathogen under such conditions is a result of selfing of $(+)$ isolates in response to the hormone produced by $(-)$ isolates. The phenomenon of hormonal heterothallism in P. splendens is similar to that commonly observed in Phytophthora ${ }^{11)}$. Mating type change occurred frequently when cultures of both $\mathrm{A}^{1}$ and $\mathrm{A}^{2}$ mating types of the cross-inducing (heterothallic) species of Phytophthora were subjected to prolonged storage ${ }^{10)}$, exposed to certain fungicides ${ }^{2,6,10,13)}$ or selfing ${ }^{1,3,4,12)}$. Mating type change also occurred in $(+)$ but not $(-)$ isolates of $P$. splendens during long-term storage ${ }^{7}$. Our attempts to induce mating type change by exposing cultures of $P$. splendens to fungicides, as mentioned above, were not successful. However, it was found that the fungus could be induced to change mating type by selfing. Details of the study are reported here.

\section{MATERIALS AND METHODS}

Isolates. Isolate $167 \mathrm{~F}$ of $(+)$ mating type and isolates $169 \mathrm{~F}$ and $117 \mathrm{~F}$ of $(-)$ mating type of $P$. splendens were each originated from a single sporangium. This is also referred to as a conidium due to its inability to release zoospores. Isolates $167 \mathrm{~F}$ and $169 \mathrm{~F}$ were recovered from cucumber ${ }^{7)}$ and isolate $117 \mathrm{~F}$ was obtained from Dr. M. Aragaki of University of Hawaii at Manoa ${ }^{15)}$. Isolates $167 \mathrm{~F}-9,167 \mathrm{~F}-27,167 \mathrm{~F}-42$ and $167 \mathrm{~F}$ 53 , also of $(+)$ mating type, were each derived from a selfed oospore of isolate $167 \mathrm{~F}$. All isolates were stored in sterile distilled water in test tubes at $24^{\circ} \mathrm{C}^{5}$.

Production of selfed-oospores. The polycarbonate membrane method described by $\mathrm{Ko}^{9)}$ was used to obtain selfed oospores. Three pieces of culture block $(15 \times 10 \times 2 \mathrm{~mm})$ of a 12 -hr-old $(+)$ mating type grown on $10 \% \mathrm{~V}-8$ agar (10\% V-8 juice, $0.02 \% \mathrm{CaCO}_{3}$ and $2 \%$ Bacto agar) were placed in the center of a petri plate $(90$ $\mathrm{mm}$ diam), covered with a polycarbonate membrane $(0.2$ $\mu \mathrm{m}, 90 \mathrm{~mm}$ diam; Nuclepore Co., Pleasanton, California 94566), and paired with the same size of V-8 agar blocks freshly inoculated with (-) mating type of isolate $117 \mathrm{~F}^{7}$. After incubation for 6 days at $24^{\circ} \mathrm{C}$ in darkness, the membrane and the $(-)$ isolate were removed and the culture blocks of $(+)$ isolate were further incubated at $24^{\circ} \mathrm{C}$ in darkness in a moist chamber for a total of 40 days. Neither $(+)$ nor $(-)$ isolate was able to grow on membrane or petri plate in the absence of agar medium to make contact with each other during the 6-day pairing.

Isolation of single oospore colonies. The methods described by Guo and $\mathrm{Ko}^{8)}$ were used to remove sporangia from oospore suspensions of $P$. splendens and to activate oospores for germination. Oospore suspensions were obtained by blending 12 culture blocks with $50 \mathrm{ml}$ sterile distilled water in an Omi mixer at 3500 rpm for $1 \mathrm{~min}$. The suspension was passed successively through $45-\mu \mathrm{m}$ and $20-\mu \mathrm{m}$ sieves. Oospores and sporan-

* Department of Plant Pathology, Beaumont Agricultural Research Center, University of Hawaii at Manoa, Hilo, Hawaii 96720, U.S.A.

** Present address : University of California, Kearney Agriculture Center, Parlier, California 93648, U.S.A. 
gia retained on the $20-\mu \mathrm{m}$ sieve were washed with 1000 $\mathrm{ml}$ tap water and resuspended in $50 \mathrm{ml}$ sterile distilled water. To eliminate sporangia, spore suspensions were incubated with an equal volume of $10 \%$ clarified V-8 juice which was prepared by centrifuging $\mathrm{V}-8$ juice at $270 \times g$ for $10 \mathrm{~min}$ and adding $0.02 \% \mathrm{CaCO}_{3}$ to the diluted supernatant. After incubation at $24^{\circ} \mathrm{C}$ overnight, germinated sporangia were separated by passage through a 45- $\mu \mathrm{m}$ screen.

The oospore suspension was mixed with an equal volume of $0.5 \% \mathrm{KMnO}_{4}$ solution and the mixture was agitated for $30 \mathrm{~min}$ on a shaker to activate the oospores. After activation, oospores were washed on the $20-\mu \mathrm{m}$ sieve with $2000 \mathrm{ml}$ of tap water followed by $300 \mathrm{ml}$ of sterile distilled water. A $20-40 \mu 1$ aliquot of this oospore suspension containing about 20 viable oospores was spread on $\mathrm{S}+\mathrm{L}$ medium ${ }^{14)}$ modified by adding $2 \%$ Bacto agar, $0.15 \%$ L-sorbose, and $100 \mu \mathrm{g} / \mathrm{ml}$ ampicillin to reduce the rate of germ tube extension and inhibit the growth of contaminants. The plates were then incubated at $24^{\circ} \mathrm{C}$ under cool white fluorescent light (2000 lux). Colonies that originated from single oospores were transferred to water agar and subcultured on $10 \% \mathrm{~V}-8$ agar plates.

Isolation of single-sporangium colonies. A culture block $(20 \times 20 \times 2 \mathrm{~mm})$ from a 6 -day-old culture grown on $10 \% \mathrm{~V}-8$ agar was cut into small pieces and blended with $50 \mathrm{ml}$ of sterile distilled water in an Omni mixer at $4500 \mathrm{rpm}$ for $1 \mathrm{~min}$. The sporangium suspension was passed successively through $45-\mu \mathrm{m}$ and $20-\mu \mathrm{m}$ sieves and the sporangia retained on the $20-\mu \mathrm{m}$ sieve were collected in $10-15 \mathrm{ml}$ of sterile distilled water. A 10-20 $\mu 1$ aliquot of the spore suspension containing about 30 sporangia was spread on a water agar plate. After incubation at $24^{\circ} \mathrm{C}$ for $2 \mathrm{hr}$, colonies that originated from a single sporangium were transferred to water agar first and then subcultured on $10 \% \mathrm{~V}-8$ agar plate.

Determination of mating type. The mating type of each isolate was determined by pairing a small piece of culture with another piece of $(+)$ tester (isolate $167 \mathrm{~F})$ or $(-)$ tester (isolate $169 \mathrm{~F})$ on a block $(15 \times 10 \times 2$ $\mathrm{mm}$ ) of V-8 agar in a petri plate. Five blocks were placed at equal distance along the edge of the plate. After incubation at $24^{\circ} \mathrm{C}$ in darkness for 6 days, those

Table 1. Mating type distribution in selfed-oospore progeny of $(+)$ isolates of Pythium splendens

\begin{tabular}{lrrrrc}
\hline \multirow{2}{*}{$\begin{array}{c}\text { Parental } \\
\text { isolate }\end{array}$} & \multicolumn{4}{c}{ Total } & \multicolumn{4}{c}{ Mating type } \\
\cline { 2 - 6 } & scored & $(+)$ & $(-)$ & $( \pm)$ & $(0)$ \\
\hline $167 \mathrm{~F}$ & 117 & 62 & 35 & 19 & 1 \\
$167 \mathrm{~F}-9$ & 37 & 23 & 7 & 5 & 2 \\
$167 \mathrm{~F}-27$ & 9 & 8 & 0 & 1 & 0 \\
$167 \mathrm{~F}-42$ & 17 & 2 & 4 & 5 & 6 \\
$167 \mathrm{~F}-53$ & 18 & 13 & 4 & 0 & 1 \\
\hline
\end{tabular}

a) Oospores were obtained by hormonal stimulation using the polycarbonate membrane method ${ }^{9}$. isolates forming oospores with the $(+)$ tester were designated (-). Similarly those forming oospores with the $(-)$ tester were designated $(+)$. Those isolates forming oospores with both $(+)$ and $(-)$ tester and in single culture were designated $( \pm)$. The $(0)$ type was used to designate the isolates that were not able to form oospores with either $(+)$ or $(-)$ tester.

\section{RESULTS}

\section{Oospore progeny of $(+)$ isolates}

When paired on the opposite sides of a polycarbonate membrane, oospores were produced by $(+)$ isolate $167 \mathrm{~F}$ but not $(-)$ isolate $117 \mathrm{~F}$ of $P$. splendens. Among the 117 selfed-oospore progeny of $(+)$ isolate obtained, $62 \mathrm{cul}$ tures were of the parental $(+)$ type, while 35 cultures become $(-)$ type (Table 1 ). The oospore progeny also included 19 self-fertile cultures belonging to $( \pm)$ type and one neuter culture belonging to (0) type. Mating type change did not occur in the asexual progeny. All the 110 single-sporangium cultures of isolate $167 \mathrm{~F}$ tested belonged to the parental $(+)$ type.

Selfed-oospore cultures were obtained from four $(+)$ isolates selected from oospore progeny of isolate $167 \mathrm{~F}$. Some members of progeny produced by three of these isolates were of the $(-)$ type (Table 1$)$. Isolates 167F-9 and $167 \mathrm{~F}-42$ produced oospore progeny consisting of $(+)$, $(-),( \pm)$ and $(0)$ types. Oospore progeny produced by isolate $167 \mathrm{~F}-53$ contained $(+),(-)$ and $(0)$ types. Among nine oospore cultures obtained from isolate $167 \mathrm{~F}-27$, eight were of the $(+)$ type and the other was of the $( \pm)$ type. About the same number of sporangium cultures obtained from each of these four isolates were all of the parental $(+)$ type.

\section{Sporangium progeny of ( \pm ) isolates}

Single-sporangium cultures were obtained from six $( \pm)$ isolates selected from oospore progeny of isolate $167 \mathrm{~F}$. The asexual progeny from all the six $( \pm)$ isolates contained both $(+)$ and $(-)$ types (Table 2 ). Three of them also included one $( \pm)$ type in their sporangium progeny.

Table 2. Mating type distribution in sporangium progeny of $( \pm)$ selfed-oospore cultures of isolate $167 \mathrm{~F}$ of Pythium splendens

\begin{tabular}{ccrcc}
\hline \hline \multirow{2}{*}{$\begin{array}{c}\text { Parental } \\
\text { isolate }\end{array}$} & \multicolumn{2}{c}{ No. of single-sporangium cultures } \\
\cline { 2 - 5 } & $\begin{array}{c}\text { Total } \\
\text { scored }\end{array}$ & \multicolumn{3}{c}{ Mating type } \\
\cline { 2 - 5 } & 17 & 10 & 6 & $(-)$ \\
\hline 1 & 21 & 2 & 19 & 0 \\
2 & 24 & 19 & 4 & 1 \\
3 & 17 & 2 & 15 & 0 \\
4 & 18 & 2 & 15 & 1 \\
5 & 18 & 5 & 13 & 0 \\
6 & & & & \\
\hline
\end{tabular}




\section{DISCUSSION}

Results from this study show that in addition to aging $^{7)}$, mating type change from $(+)$ to $(-)$ in $P$. splendens can also occur as a result of selfing. The mating type did not change from $(-)$ to $(+)$ even during longterm storage ${ }^{7}$. It is, therefore, considered possible that in $P$. splendens sexual reproduction may have started only after the conversion of certain ancestral members from the original $(+)$ to $(-)$ type during the evolutionary process. Therefore, the possible evolutionary origin of sex in this species differs from that of the closely related species of Phytophthora in which both $\mathrm{A}^{1}$ and $\mathrm{A}^{2}$ types can be changed to the opposite type during longterm storage ${ }^{10)}$ or as a result of exposure to various fungicides ${ }^{2,6,10,13)}$.

It is conceivable that similar to the mechanism postulated by $\mathrm{Ko}^{10)}$ for Phytophthora, the expression of mating type in heterothallic species of Pythium may be regulated by a repressor which represses the expression of $(+)$ mating type with one molecular configuration, and $(-)$ mating type with another configuration. Selfing may have changed the mating type by reversing the function of the repressor.

The self-fertile character of $( \pm)$ type that resulted from selfing of $(+)$ isolates of $P$. splendens is unstable and appears to be a transitional state in the process of mating type change from $(+)$ to $(-)$ because almost all their asexual progeny were either $(+)$ or $(-)$ type. Unstable self-fertile $\left(\mathrm{A}^{1} \mathrm{~A}^{2}\right)$ had also been generated by an $\mathrm{A}^{1}$ isolate of Phytophthora parasitica Dast. through aging $^{10)}$ and Phytophthora infestans (Mont.) de Bary through exposure to metalaxy ${ }^{6)}$ and by an $\mathrm{A}^{2}$ isolate of $P$. parasitica through exposure to chloroneb ${ }^{10)}$. Both $\mathrm{A}^{1}$ and $\mathrm{A}^{2}$ isolates of Phytophthora cinnamomi Rands also generated $\mathrm{A}^{1} \mathrm{~A}^{2}$ type after being exposed to chloroneb or ethazol ${ }^{21}$.

Conversion of $(+)$ type to neuter (0) type in $P$. splendens as a result of selfing is unique. Neuter type $\left(\mathrm{A}^{0}\right)$ which has been found in various species of Phytophthora has never been generated in the process of mating type change in this genus ${ }^{11}$

We thank Dr. M. Aragaki for isolate $117 \mathrm{~F}$ of $P$. splendens used in this study. Journal Series No. 4115 of the Hawaii Institute of Tropical Agriculture and Human Resources.

\section{Literature cited}

1. Ann, P.J. and Ko, W.H. (1988). Hormonal heterothallism in Phytophthora parasitica: a novel mode of sexual reproduction? J. Gen. Microbiol. 134 : 2985-2992.

2. Ann, P.J. and Ko, W.H. (1989). Effect of chloroneb and ethazol on mating type of Phytophthora parasitica and $P$. cinnamomi. Bot. Bull. Acad. Sin. 30 : 207-210.

3. Ann, P.J. and Ko, W.H. (1990). Survey of enzyme activity on solid media in Phytophthora. Can. J. Bot. 69 : 139-143.

4. Ann, P.J. and Ko, W.H. (1990). Growth rate and colony morphology of progenies of zoospores and selfed oospores of Phytophthora parasitica. Mycologia 82 : 693697.

5. Boesewinkle, H.J. (1976). Storage of fungal culture in water. Trans. Br. Mycol. Soc. 66 : 183-185.

6. Chang, T.T. and Ko, W.H. (1990). Effect of metalaxyl on mating type of Phytophthora infestans. Ann. Phytopathol. Soc. Jpn. 56 : 194-198.

7. Guo, L.Y. and Ko, W.H. (1991). Hormonal regulation of sexual reproduction and mating type change in heterothallic Pythium splendens. Mycol. Res. 95 : 452456.

8. Guo, L.Y. and Ko, W.H. (1994). Factors affecting oospore germination of heterothallic Pythium splendens. Mycologia $86: 777-780$.

9. Ko, W.H. (1978). Heterothallic Phytophthora: Evidence for hormonal regulation of sexual reproduction. J. Gen. Microbiol. 107 : 15-18.

10. Ko, W.H. (1981). Reversible change of mating type in Phytophthora parasitica. J. Gen. Microbiol. 125 : 451-454.

11. Ko, W.H. (1988). Hormonal heterothallism and homotha!lism in Phytophthora. Annu. Rev. Phytopathol. 26: $57-73$.

12. Ko, W.H. (1994). An alternative possible origin of the $\mathrm{A}^{2}$ mating type of Phytophthora infestans outside Mexico. Phytopathology 84 : 1224-1227.

13. Ko, W.H., Lee, C.J. and Su, H.J. (1986). Chemical regulation of mating type in Phytophthora parasitica. Mycologia 78: 134-136.

14. Ruben, D.M., Frank, Z.R. and Chet, I. (1980). Factors affecting behavior and developmental synchrony of germinating oospores of Pythium aphanidermatum. Phytopathology 70 : 54-59.

15. Yamamoto, B.T. and Aragaki, M. (1983). Etiology and control of seedling blight of Brassaia actinophylla caused by Pythium splendens in Hawaii. Plant Dis. 67 : 396-399.

\section{和 文 摘：要}

Li-Yun Guo・Wen-Hsiung Ko：自殖によって誘導された Pythium splendens の交配型の変化

Pythium splendens の $(+)$ 型と $($ 一)型の分離株をポリカーボ ン膜の表裏に接触させて培養すると, (十)株側では自殖により 卵胞子が形成されたが，(一)側では形成されなかった。この方法 により，(+)株側では形成された卵胞子の後代の交配型を検定 した結果，ほとんどの株でもとの $(+)$ 型に加え，正反対の $(-)$ 型も出現することが明らかになった。さらに自家和合性の $( \pm)$ 型や無性の $(0)$ 型も検出された。 $( \pm)$ 株の自家和合性の性質は不 安定で一時的であり, 無性生殖により $(+)$ 型と $($ - 型に分離し た。本実験より, 自殖は, 異なった分子配列により交配型の表現 を制御しているレプレッサーの機能を変えることによって, 交 配型を変化させたのではないかと想定される。 